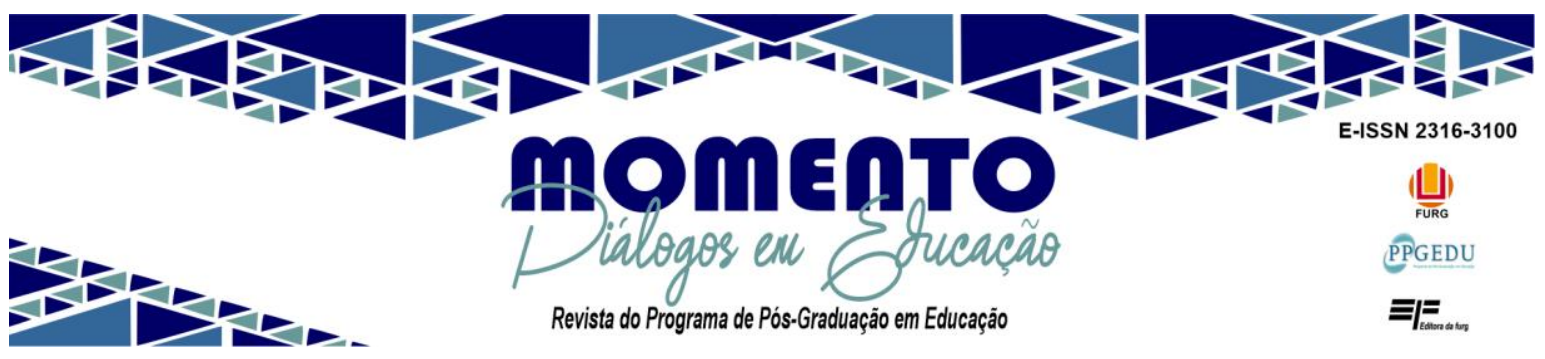

\title{
A DIFUSÃO DAS BOAS MANEIRAS UNIVERSAIS POR MEIO DOS MANUAIS DO PABAEE-INEP
}

\author{
Márcia Santos ${ }^{1}$ \\ Susane Waschinevski ${ }^{2}$
}

Resumo: Este estudo tem como proposta dialogar sobre a difusão das boas maneiras por meio de manuais de leitura e ensino, em especial nos manuais da "Coleção Biblioteca de Orientação da Professôra Primária" do Programa de Assistência Brasileiro-Americana ao Ensino Elementar (PABAEE-INEP), entre os anos de 1956-1964. No sentido de refletir sobre tais leituras inseridas como mecanismos de circulação e difusão de modos desejados para constituição de uma sociedade moderna, buscou-se vislumbrar interfaces entre os manuais da referida Coleção e manuais de autoria norte-americana, comercializados no Brasil no mesmo período, com vistas a evidenciar como a escolarização se inscreve em determinados projetos de sociedades e seu processo civilizador. Tal estudo buscou dialogar com pesquisas no campo da História da Educação, em especial a escolarização entrevista pelas relações entre os materiais de formação produzidos dentro e fora do âmbito escolar.

Palavras-chave: Formação Docente. Escolarização. Manuais PABAEE-INEP. Boas maneiras.

\section{THE POLITENESS DISSEMINATION THROUGH FROM THE PABAEE-INEP MANUALS}

\begin{abstract}
This article proposes to dialogue about the dissemination of politeness through reading and teaching manuals, especially in the manuals of the "Guidance Library Collection of the Primary Teacher" of the Brazilian-American Assistance Program for Elementary Education (PABAEEINEP), between the years 1956-1964. In order to reflect on such readings inserted as mechanisms for the circulation and dissemination of the desired good manners for the constitution of a modern society, we sought to glimpse interfaces between the manuals of the aforementioned Collection and the manuals of good manners of North American authorship, marketed in Brazil in the same period, with a view to showing how schooling is inscribed in certain projects of societies and their civilizing process. This study sought to dialogue with research in the field of History of Education, in particular,
\end{abstract}

\footnotetext{
${ }^{1}$ Doutora em História pelo Programa de Pós-Graduação em História da Universidade do Estado de Santa Catarina (UDESC/2019), com área de concentração em História do Tempo Presente, na linha de pesquisa Políticas de memória e narrativas históricas. Mestre pelo Programa de Pós-Graduação em Educação, na linha de pesquisa História e Historiografia da Educação (UDESC/2015) e possui Bacharelado e Licenciatura em História (UDESC/2003). É membro da Associação Nacional dos Professores Universitários de História (ANPUH). Participante do Grupo de Pesquisa Ensino de História, memória e culturas (CNPq) e do Grupo de Estudos História, Cultura Escrita e Leitura (GEHCEL). Tem experiência docente no ensino básico, como celetista, e superior, como estagiária, nas áreas de Educação e História. As pesquisas desenvolvidas tiveram ênfase em História do Tempo Presente, História da Educação e História da Cultura Escrita.

${ }^{2}$ Possui graduação (licenciatura e bacharelado) em Geografia (2013) pela Universidade do Extremo Sul Catarinense (UNESC), mestrado em Educação na mesma instituição. Especialização em Educação Profissional Integrada à Educação Básica na Modalidade EJA (PROEJA), em 2019 pelo Instituto Federal de Santa Catarina (IFSC) e doutorado em Educação (2020) pela Universidade do Estado de Santa Catarina (UDESC), na linha de Pesquisa: História e Historiografia da Educação. Membro do Grupo de Pesquisa Ensino de História, Memória e Culturas. Participa do Grupo de Estudos História, Cultura Escrita e Leitura (GEHCEL) vinculados ao Laboratório de Patrimônio Cultural (LapPac - UDESC).
} 


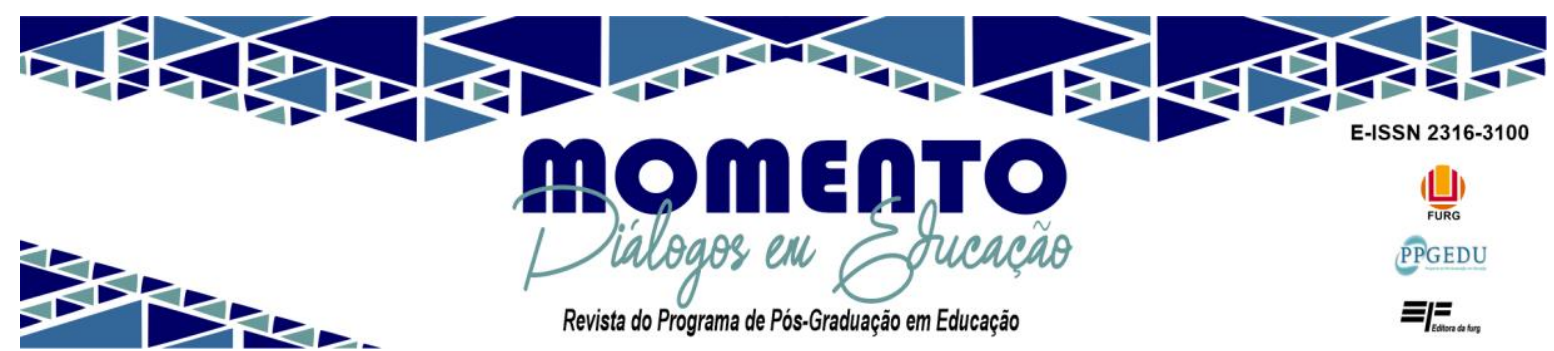

schooling interviewed by the relationships between training materials produced inside and outside the school environment.

Keywords: Teacher Training. Schooling. PABAEE-INEP Manuals. Politeness.

\section{LA DIFUSIÓN DE LOS BUENOS MODALES UNIVERSALES A TRAVÉS DE DE LOS MANUALES PABAEE-INEP}

Resumen: Este estudio propone dialogar sobre la difusión de la buena educación a través de la lectura y los manuales didácticos, especialmente en los manuales de la "Colección Bibliotecaria de Orientación Docente de Primaria" del Programa Brasileño-Americano de Asistencia a la Educación Primaria (PABAEE-INEP), entre los años 1956 -1964. Con el fin de reflexionar sobre tales lecturas insertas como mecanismos de circulación y difusión de las buenas costumbres deseadas para la constitución de una sociedad moderna, se buscó vislumbrar interfaces entre los manuales de la citada Colección y los manuales de buenas costumbres de autoría norteamericana comercializado en Brasil en el mismo período, con miras a mostrar cómo la escolarización se inscribe en ciertos proyectos de sociedades y su proceso civilizador. Este estudio buscó dialogar con la investigación en el campo de la Historia de la Educación, en particular, la escolarización entrevistada por las relaciones entre los materiales formativos producidos dentro y fuera del ámbito escolar.

Palabras clave: Formación de Profesores. Enseñanza. Manuales PABAEE-INEP. Buenas Maneras.

\section{Introdução. Boas maneiras universais nos manuais do PABAEE-INEP}

Durante os anos de 1950 e 1960, vivia-se no Brasil uma série de campanhas governamentais destinadas a diferentes setores da sociedade, com o objetivo de promover a modernização do país por meio de políticas voltadas a suprir um quadro problemático de carência, ao mesmo tempo que se desejava promover o crescimento econômico. Tais campanhas tinham como contexto a efervescência dos "anos dourados", período marcado por discursos pró-modernização e imbuídos das ideias desenvolvimentistas.

Com Juscelino Kubistchek (1956-1961) na presidência da República, acentuou-se a implantação da indústria pesada, iniciada nos governos de Getúlio Vargas. A economia do país também ganhou novas formas, ao promover a abertura ao capital internacional. JK tinha como projeto a modernização do país, em especial os incentivos ao setor industrial. Uma de suas medidas foi a apresentação do importante Plano de Metas, que previa o fortalecimento da indústria de base, consolidando o processo de industrialização brasileira. Esse Plano consistiu em 30 metas e a meta-síntese: a construção de Brasília, sendo considerada por muitos economistas a primeira experiência de planejamento posta em prática no país (WASCHINEWSKI, RABELO, 2019). 


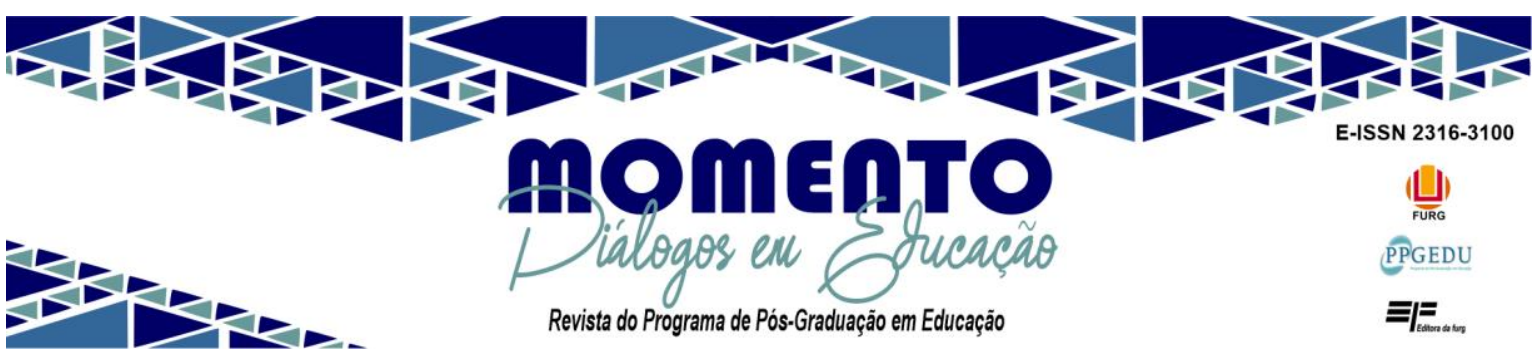

Em consonância com o projeto modernizador, foram criados diversos órgãos governamentais responsáveis pela produção de dados, pesquisas e elaboração de propostas para políticas públicas que visassem a superar um quadro nacional visto como atrasado e carente: em 1953, a Lei $n^{\circ} 1.920$ apresenta em seus artigos $1^{\circ}$ e $2^{\circ}$ o desdobramento dos Ministérios da Saúde e Educação, sendo assim criados o Ministério da Saúde e o Ministério da Educação; em 1955, ocorreu a criação do Instituto Superior de Estudos Brasileiros (ISEB) por intermédio do Decreto $\mathrm{n}^{\circ} 37.608$, como órgão do Ministério da Educação e Cultura, tendo como objetivos conhecer a realidade brasileira, divulgar as ciências sociais e promover o desenvolvimento social.

Uma dessas campanhas foi pensada para o setor educacional por meio de um convênio firmado entre Brasil e Estados Unidos, chamado "Programa de Assistência Brasileiro-Americana ao Ensino Elementar (PABAEE-INEP)", sendo assinado no dia 22 de junho de 1956, durante o governo de JK, pelo ministro da Educação, Clóvis Salgado da Gama (1956-1960), e pelo governador de Minas Gerais, José Francisco Bias Fortes (19561961), em parceria com o Instituto Nacional de Estudos e Pesquisas Educacionais Anísio Teixeira (INEP). A sede do Programa estava localizada no estado de Minas Gerais, mais precisamente no Instituto de Educação de Belo Horizonte, cujo prédio foi reformado para receber professores(as) de diversos estados brasileiros (WASCHINEWSKI, 2020).

Com foco no aperfeiçoamento dos profissionais brasileiros, o Programa tinha como objetivo melhorar os índices educacionais da época, como o abandono escolar e a repetência. Tinha-se o entendimento que muitos dos problemas educacionais poderiam ser resolvidos com a melhor qualificação de professores(as) e que, com a escolha de determinadas parcerias internacionais, poderia ser elevado o desempenho da educação no país. A seguir, podem ser observados os objetivos detalhados do PABAEE-INEP:

Dos objetivos

1. Formar quadros de instrutores de professores de ensino normal para diversas das Escolas Normais mais importantes do Brasil.

2. Elaborar, publicar e adquirir textos didáticos, tanto para as Escolas Normais como para Elementares.

3. Enviar aos Estados Unidos, pelo período de um ano, na qualidade de bolsistas, cinco grupos de instrutores de professôres de ensino normal e elementar, recrutando nas regiões representativas do Brasil, para integrarem os quadros de instrutores pelo período mínimo de dois anos (BRASIL, 1957 apud PAIVA, PAIXÃO, 2002, p. 171). 


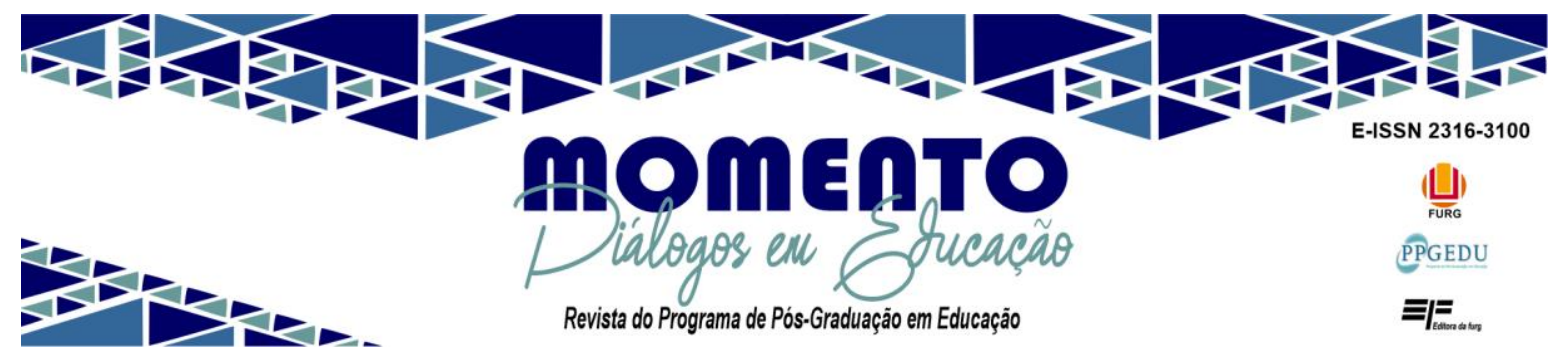

Em um dos documentos produzidos pelo convênio e intitulado "Relatório do

Programa de Assistência Brasileiro-americana ao Ensino Elementar (1956-1964)", tem-se o registro de participação de 864 professores(as) bolsistas, representando 25 estados brasileiros. Segundo Paiva e Paixão (2002, p. 150),

[...] foram distribuídas 142 bolsas de estudos para realização de cursos nos EUA. Alguns brasileiros obtiveram duas bolsas em períodos diferentes, 130 dessas bolsas foram para cursos na Universidade de Indiana e $12 \mathrm{em}$ outras universidades.

De acordo com o segundo objetivo do Programa, "elaborar, publicar e adquirir textos didáticos tanto para as Escolas Normais como para Elementares", um desses materiais, construídos especialmente para as professoras utilizarem na preparação de suas aulas, foi a Coleção "Biblioteca de Orientação da Professôra Primária" (Figura 1), composta por sete volumes, cada um voltado para uma área formação, sendo eles: "Ver, sentir, descobrir a Aritmética"; "Experiências de Linguagem Oral"; "Formação e desenvolvimento de conceitos"; "O que é Jardim de Infância"; "Testes, medidas e avaliação"; "Ciências na Escola Moderna" e "Habilidades de Estudos Sociais".

Figura 1: Capas da Coleção "Biblioteca de Orientação da Professôra Primária".
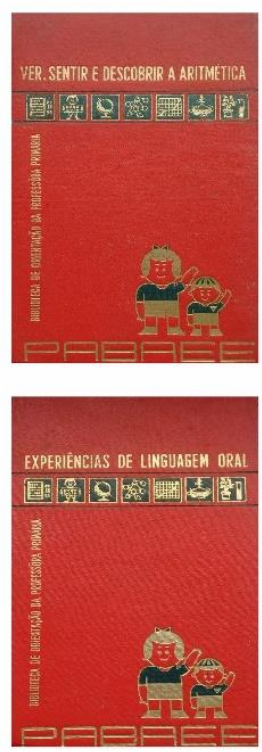
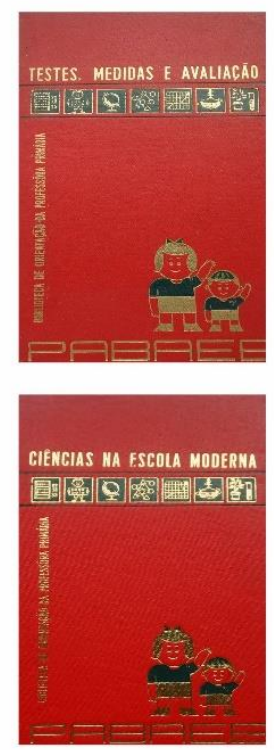
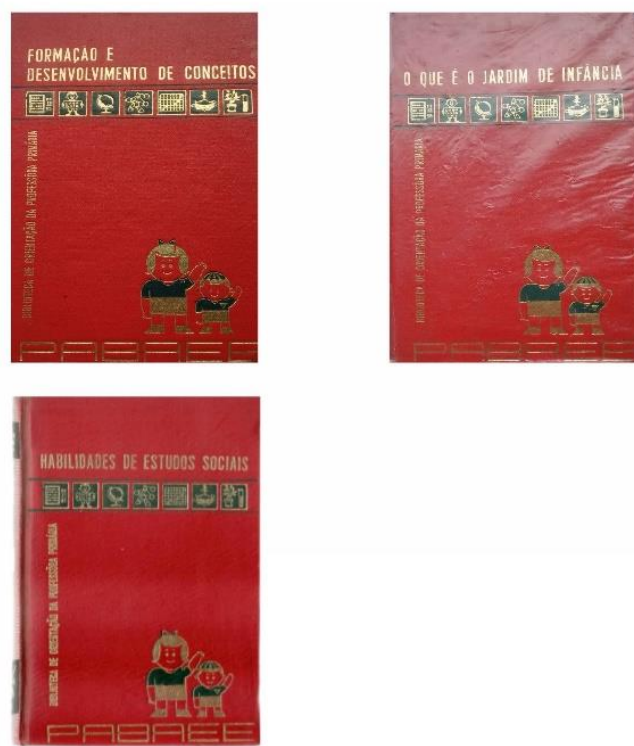

Fonte: Elaborado pelas autoras com base na coleção Biblioteca de Orientação da Professôra Primária. Acervo GRUPEHME. 


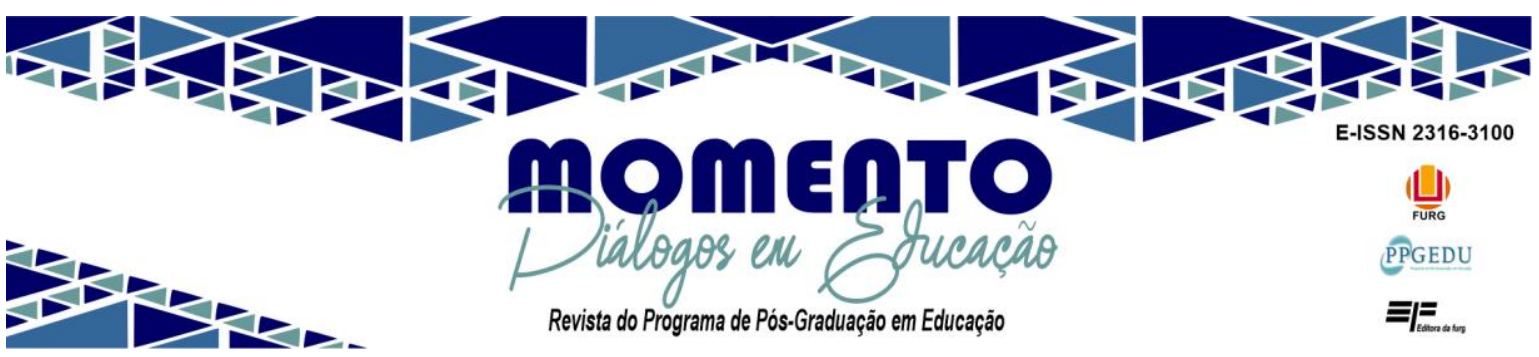

As inscrições em sua contracapa indicam que essas edições foram publicadas em 1965, pela Editora Nacional de Direito, no Rio de Janeiro, com as seguintes informações: "Edição autorizada pelo Programa de Assistência Brasileiro-Americana ao Ensino Elementar PABAEE, Belo Horizonte (MG) e Instituto Nacional de Estudos Pedagógicos, Ministério da Educação e Cultura, Rio de Janeiro (GB)". Tais vestígios indicam a consonância com as premissas do Programa. A Coleção é composta por sete volumes, todos com capa dura, de cor vermelha, com inscrições em cor dourado, destacando, abaixo dos títulos dos volumes, uma faixa contendo símbolos para representar cada área do conhecimento e seus respectivos manuais e, na base inferior direita, uma ilustração de uma mulher e uma criança, como referência a uma professora e seu aluno. As cores das ilustrações se harmonizam com o vermelho utilizado no fundo e as letras em dourado.

Tais manuais evidenciam em sua materialidade a imponência que o Programa buscava estabelecer, não apenas do ponto de vista educacional com suas propostas "modernas" de ensino, mas também a própria escolha das cores, a capa dura, os materiais selecionados para a impressão, indícios esses que demonstram uma intenção de perenizar. Considerada a capa de uma publicação como protocolo de leitura (CHARTIER, 1990), a Coleção se apresentava suntuosa, idealizada para se destacar nas estantes, chamar a atenção de um público intelectual de gostos refinados, assim como, por exemplo, as futuras professoras. Para além da estética, pensou-se, igualmente, na longevidade da obra, afinal, caso fossem impressos em papéis mais frágeis, dificilmente teriam sobrevivido por quase 60 anos após a sua publicação.

A construção dos manuais do PABAEE-INEP está imbricada de muitas questões que envolvem os modos de produção/reprodução e o seu consumo, constituindo assim uma complexa fonte de pesquisa, ao mesmo tempo que permite observar traços referentes à educação, à cultura ou às mentalidades, à linguagem, às ciências, ao seu suporte e à sua produção. "O manual é, realmente, um objeto complexo dotado de múltiplas funções, a maioria, aliás, totalmente despercebido aos olhos dos contemporâneos" (CHOPPIN, 2002, p. 13). O conjunto formado por autoria, conteúdos escolhidos, projeto gráfico e qualidade dos materiais se inscreve nos significados que a obra desdobra ao longo do percurso de sua circulação, bem como na sua duração no tempo. Manuais de formação são concebidos para 


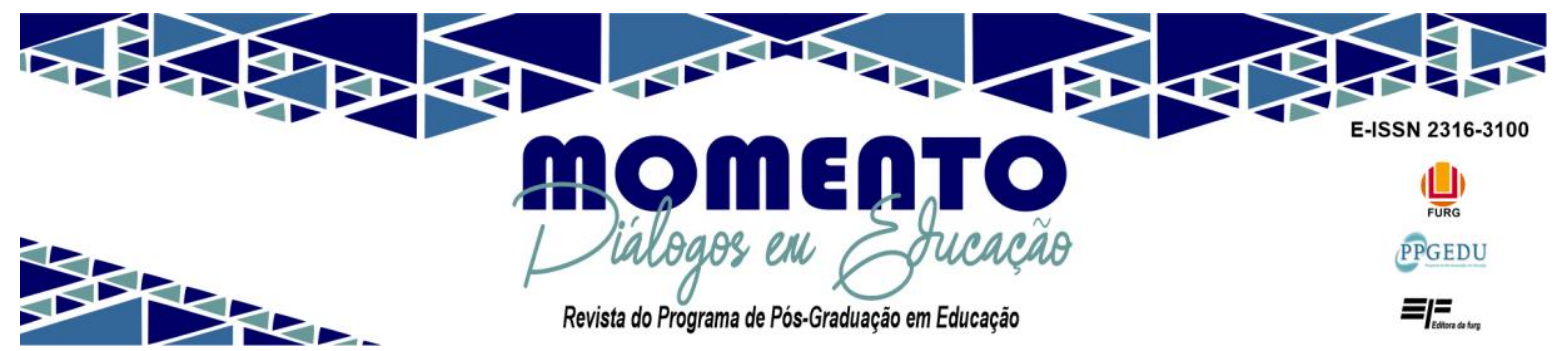

serem internalizados e, para tanto, mobilizam estratégias de interlocução que dissimulam, mesmo em frente ao olhar do mais atento leitor.

Pensando sobre suas possibilidades de análise, propõe-se colocar em perspectiva os vestígios sobre noções de boas maneiras presentes nos manuais do PABAEE como elementos fundantes de uma sociedade moderna. À luz de um processo civilizador inscrito na escolarização, partiu-se da ideia de uma vinculação da educação aos modos ditos universais como uma estratégia para padronizar modos, construindo ajustamento social.

Apresentadas essas palavras iniciais que contextualizam a escrita, pretende-se, neste estudo, problematizar a difusão das boas maneiras prescritas por meio de manuais de leitura e ensino no Brasil entre as décadas de 1950 e 1960. Para tal investimento, privilegiou-se como corpus documental o manual "O que é Jardim de Infância", da Coleção do PABAEE. A escolha desse manual, que integra a coleção, destinado ao uso dos professores primários brasileiros, se dá pela possibilidade analítica de evidenciar como a educação escolarizada, desde suas fases iniciais, estava inserida em um projeto civilizador.

A escrita deste artigo, após esta parte introdutória, é seguida do diálogo entre os manuais do PABAEE-INEP e os preceitos de boas maneiras observados em manuais de autoria norte-americana, comercializados no Brasil no mesmo período. Por fim, propõe refletir sobre a circulação e a difusão dessas obras em território nacional, em especial dos manuais do PABAEE-INEP que alcance nacional, devido à realização dos cursos de aperfeiçoamento e à comercialização dos materiais didáticos produzidos pelo referido Programa.

Ao traçar tais objetivos de investigação, tem-se em mente que "[...] o manual funciona assim, ao mesmo tempo, como um filtro e como um prisma: revela bem mais a imagem que a sociedade quer dar de si mesma do que sua verdadeira face" (CHOPPIN, 2002, p. 18). Corroborando as ideias de Choppin, é possível observar indícios de qual modelo de sociedade esperava-se constituir, tendo como um de seus pilares a educação, bem como entrever um modelo de professor(a), uma proposta de escola e corpos a civilizar.

Sob a perspectiva de como as relações sociais se constroem de forma coletiva, Elias (1993, p. 202) afirma que "desde o começo da mocidade, o indivíduo é treinado no autocontrole e no espírito de previsão dos resultados de seus atos, de que precisará para desempenhar funções adultas”. Dessa forma, a escolarização, compreendida aqui “[...] como 


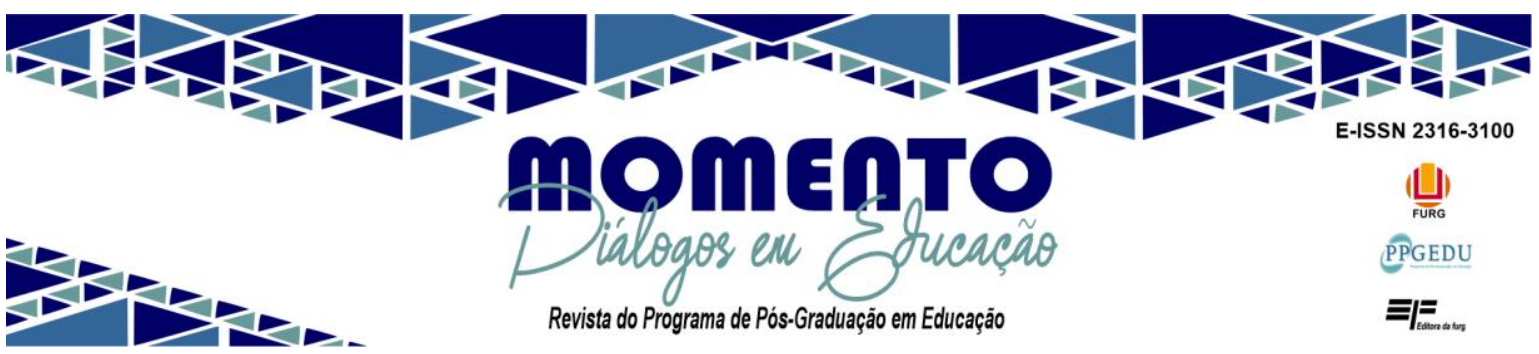

a produção de representações sociais que tem na escola o locus fundamental de articulação e divulgação de seus sentidos e significados" (FARIA FILHO, 2007, p. 194), é convergente nesse processo, entretanto, a forma como ocorre essa intervenção desencadeia maneiras diversas de existir na sociedade ao alcançar a idade adulta. Todavia, as concepções admitidas para interagir em um processo educativo dialogam com o tempo e o espaço que as circunscrevem e, por conseguinte, são escolhas realizadas para efetivar determinados projetos de sociedade. Há inúmeras formas de disseminar tais projetos, mas, por ora, leituras de formação - escolarizadas ou não - serão os meios privilegiados para se aproximar de narrativas que se propõem a servir de base para novas organizações sociais.

\section{Manuais do PABAEE-INEP e preceitos de boas maneiras: ajustamentos sociais em construção}

Êste relatório, preparado de acôrdo com as normas padronizadas pelo corpo docente e demais funcionários do PABAEE, aprovado pelos representantes do Ministério de Educação e Cultura do Brasil, Govêrno do Estado de Minas Gerais e Missão Norte-Americana de Cooperação Econômica e Técnica no Brasil, apresenta as realizações do Projeto de Educação Elementar e recomendações para ação futura.

A cooperação e as excelentes relações de trabalho estabelecidas entre o pessoal brasileiro e o americano ligados a êste projeto foram um exemplo de boa vontade e amizade internacional (PROGRAMA DE ASSISTÊNCIA..., 1964, p. V).

Assim afirmava a declaração do Relatório ao término do projeto, expressamente assinada por autoridades educacionais brasileiras e norte-americanas. O prólogo, devidamente autenticado, destacou o êxito do Projeto e o vínculo amistoso entre os profissionais envolvidos no seu desenvolvimento. Atingido o objetivo de assistir à educação elementar brasileira, o documento traduzido com o auxílio de professores e técnicos estadunidenses, relatou as etapas organizacionais, a seleção de participantes, as práticas desenvolvidas, os materiais produzidos e os investimentos financeiros realizados. Harmonioso e transparente, o Relatório documentou a proposição de inserir metodologias e culturas escolares no sistema educacional brasileiro, que eram compreendidas como exitosas. Atendendo aos objetivos do PABAEE, essas interlocuções se deram por meio do desenvolvimento de materiais de formação para normalistas, bem como publicações destinadas à escolarização chamada de "elementar". As últimas destacavam a necessidade 


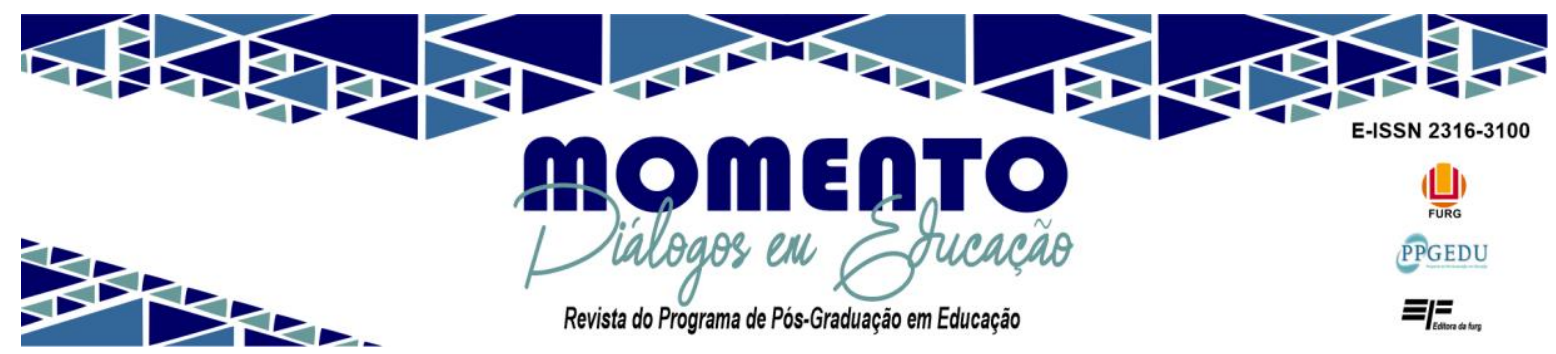

de formação desde a mais tenra idade, lastreando a instituição dos Jardins de Infância como parte da educação escolarizada.

A instituição de um nível de escolarização anterior aos anos iniciais do Ensino Fundamental demandava um projeto educacional específico que contemplasse as possibilidades de atendimento para esse tipo de grupo. A escolarização anterior à alfabetização propriamente dita deveria ser dedicada à construção de valores e preceitos entendidos como importantes naquele contexto social; dessa forma, as professoras deveriam buscar leituras convergentes com tais premissas. Em estudo que tratou da formação de professoras entre as décadas de 1930 e 1960, a historiadora Maria Teresa Santos Cunha (2005, p. 123) inferiu que "[...] os manuais de civilidade eram considerados vetores de sistemas de valores, ferramentas para consolidação das formas e dos códigos morais e sociais". Dessa forma, esse tipo de literatura figurava entre os materiais de formação utilizados em Escolas Normais ${ }^{3}$. A preparação do indivíduo para o convívio em sociedade era matéria presente no cotidiano das escolas e considerado um elemento significativo para o êxito escolar. O fato de ter, majoritariamente, mulheres na formação elementar denota uma continuidade da educação doméstica, em um ambiente aprazível para crianças. Dessa forma, os manuais de civilidade, como apresentavam maneiras para o âmbito privado e público, se faziam úteis no intuito de ilustrar a prática docente das normalistas, no sentido de que seus ensinamentos e valores se espraiavam para além de uma cultura escolar constituída.

Os livros de etiqueta e boas maneiras eram literaturas de formação complementares, as quais tinham espaço fora do ambiente escolarizado. Considerando algumas publicações de autoria estadunidense que foram traduzidas e comercializadas no Brasil, é possível perceber aproximações com a perspectiva do PABAEE-INEP, como, por exemplo, um estreitamento do diálogo com a cultura norte-americana. A tradução de publicações estrangeiras era uma forma de aproximar leitores brasileiros de universos simbólicos de práticas sociais elaboradas por outras culturas, especialmente as ocidentais. Inclusive, é importante destacar que na biblioteca central do Programa, que ficava na capital mineira, foram recebidas muitas obras traduzidas para o português, com o intuito de que pudessem circular de forma mais acessível às professoras em aperfeiçoamento. Aspecto esse que

\footnotetext{
${ }^{3}$ Denominação pela qual eram conhecidos os centros de formação onde estudavam, majoritariamente, mulheres e se tornavam professoras de Ensino Fundamental I, chamado na época de nível primário.
} 


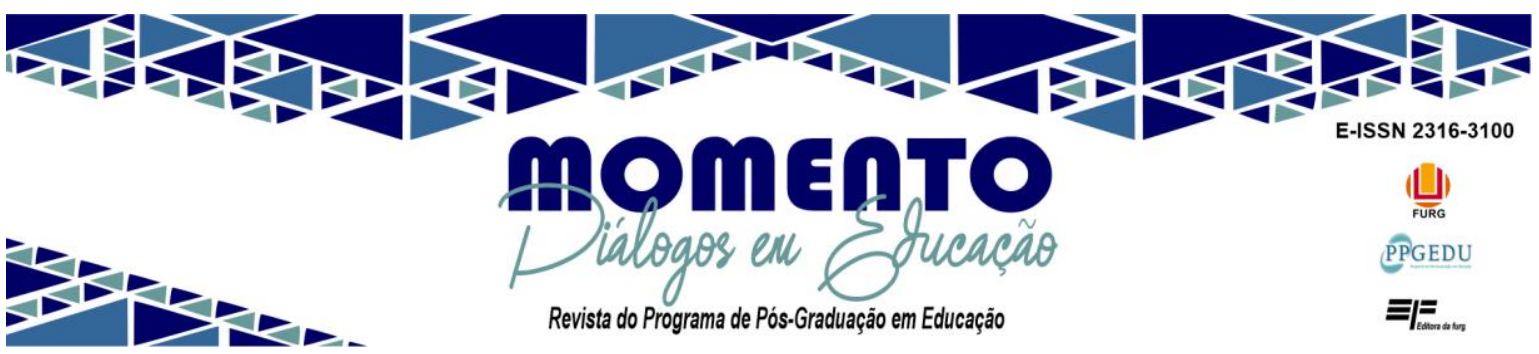

permite refletir sobre uma tendência em reconhecer nos EUA uma referência cultural e pedagógica, servindo de inspiração e aporte teórico.

O desejo de estabelecer sintonia com tais práticas era acompanhado de estereótipos que compreendiam as culturas de alguns países como mais aprimoradas e, portanto, passíveis de serem apropriadas como uma forma de criar modos universais de convivência. Sob a perspectiva de um processo civilizador (ELIAS, 1993), no qual as transformações sociais são impulsionadas por circunstâncias coletivas que atuam sobre atitudes individuais, a longevidade de algumas nações qualificava um repertório de modos sociais, servindo, assim, como parâmetro em outros espaços. Conectar-se ao referencial cultural e pedagógico norteamericano vislumbrava aproximar-se das tendências mais recentes, das propostas mais assertivas, de uma concepção de sociedade moderna, que deveria ter como um de seus pilares uma educação moderna, com propostas pedagógicas consideradas inovadoras.

Para além de acordos comerciais e cooperação internacional, o intuito de aproximação cultural entre Brasil e EUA pode ser entrevisto pela ótica da hierarquia e da hegemonia. No meio educacional, o desejo de inovar era circunscrito pelo desejo de superação de práticas consideradas fora da validade. Segundo o manual nomeado "O que é Jardim de Infância”, da autora Nazira Féres Abi-Sáber, publicado em 1965, produzido para os cursos do PABAEE-INEP, “[...] temos, via de regra, imbuído, ainda, aquêle espírito latino-americano que dá mais valor aos 'conhecimentos verbais', às 'coisas a serem aprendidas', do que ao desenvolvimento harmoniosa da personalidade" (ABI-SÁBER, 1965, p. 29), fazendo uma referência depreciativa às tradições orais de aprendizado e ao conhecimento cultural acumulado. Os referenciais próprios sob os quais se constitui uma sociedade deveriam ceder espaço aos conceitos considerados modernos. Ainda segundo a autora,

Sonhamos com um tempo, não muito distante, em nossos Jardins de Infância, em geral, hão de dar o grito de alarme e iniciarão um ensino criador baseado na livre iniciativa da criança e no aproveitamento de tôda sua capacidade inventiva.

Quando chegar esse têmpo, nossas escolas pré-primárias serão verdadeiros campos de experimentação e criação, verdadeira forja de nossos futuros inventores e cientistas. (ABI-SÁBER, 1965, p. 29). 


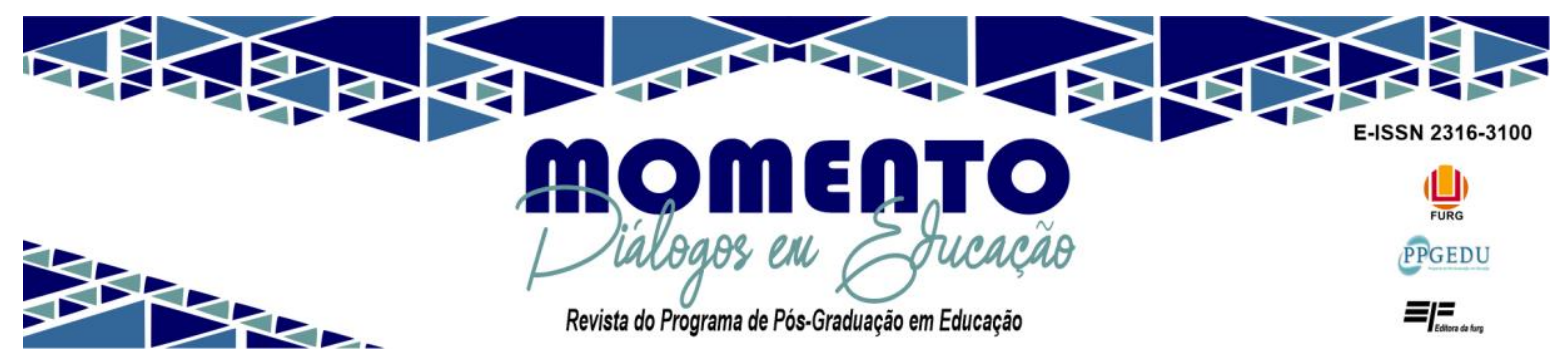

Com vistas a instituir novas práticas de ensino, os Jardins de Infância contribuiriam para uma sociedade diferente, sustentada por outros paradigmas. Em diálogo com Vincent, Lahire e Thin, Faria Filho (2007) aborda a forma de socialização específica que é configurada pela escola e como essas relações extrapolam a cultura escolar e se espraiam nas sociedades. Considerando que há um "[...] processo de submetimento de pessoas, conhecimentos, sensibilidades e valores aos imperativos escolares" (FARIA FILHO, 2007, p. 195), os conceitos admitidos para ancorar um projeto educacional são escolhas que configuram os saberes a serem multiplicados por meio da escolarização. A competência dessas escolhas se vincula aos valores e entendimentos que devem ser potencializados pelo processo de formação escolar. Com seus métodos e suas práticas consideradas inovadoras, os Jardins de Infância desejavam "forjar" inventores e cientistas.

A narrativa se aproxima sobremaneira da cultura escolar do século XXI, que tem introduzido conceitos advindos da área corporativa na construção de práticas escolares. Metodologias utilizadas no presente dessa escrita, como "educação 4.0" ou "educação maker", poderiam ser o referencial de Abi-Sáber se sua produção não tivesse sido escrita na década de 1960. Esses indícios sugerem tentativas de transformação nas práticas escolares brasileiras com a introdução de conceitos educacionais inspirados em uma cultura liberal, com a licença de utilizar essa expressão sem reportar, nesse momento, ao aspecto econômico que a acompanha. Não se pode desconsiderar que as publicações analisadas estão alocadas no contexto mundial de formação de zonas de influência pelas doutrinas capitalista e comunista, conflito que norteava as relações internacionais dos EUA, bem como configurava as parcerias que pretendia firmar. Sendo assim, expandir a cultura para países carentes de determinados recursos - segundo a ótica estadunidense - seria uma forma de demonstrar amizade ao mesmo passo que expandir práticas culturais. De forma sutil, estabeleciam-se relações de lealdade internacional.

A promoção de literaturas de formação estrangeiras disponibiliza modos a serem conhecidos e apropriados, entretanto, quando estes ressoavam sobre literaturas institucionais, diminuíam significativamente a autonomia de escolha, principalmente quando se destinavam à formação de crianças. Essa interlocução entre expansão (por parte dos EUA) e pertencimento (por parte do Brasil) funcionava como estímulo em um país que vivenciava um processo crescente de urbanização e a emergência de novos grupos sociais ansiosos por 


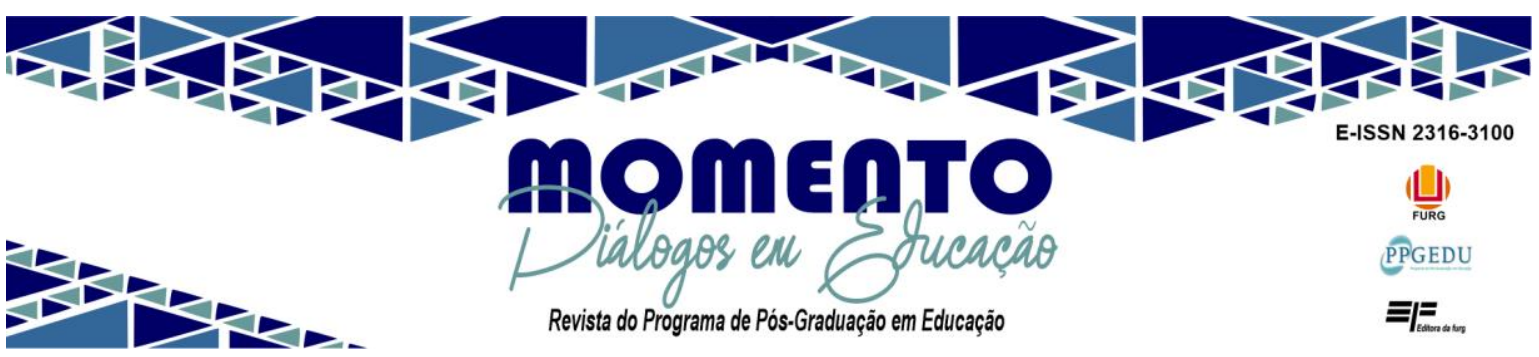

ilustração, em função da necessidade de adaptação aos ambientes dos quais se desejava compartilhar. Para tanto, era fundamental conhecer as maneiras que mediavam as relações nos espaços onde se desejava circular.

A cortesia, uma vez que é sempre atual, deve guardar a sua força de adaptação. [...] Há usos e costumes sociais que variam segundo as latitudes, pois a cortesia não é privilégio exclusivo de nenhum meio restrito. Entretanto, alguns aspectos da polidez, por isso mesmo que se originam na lei natural da ética humana, são mais ou menos universais (WILSON, 1947, p. 13).

A narrativa contida no livro Cortesia, da autora norte-americana Margery Wilson ${ }^{4}$, remete à ideia de modos intrínsecos ao processo de desenvolvimento dos diversos tipos de sociedades e lhes atribui um caráter universalizante. A autora considerou a existência de uma "lei natural da ética humana" propulsora da transformação dos modos sociais. Essa afirmação tem como parâmetros estratégias de convivência conhecidas e aprovadas em uma cultura específica, entretanto isso não impossibilitou lhe atribuir exemplaridade. $\mathrm{O}$ espaço social e geográfico onde se construiu a narrativa - uma classe intelectual privilegiada de um país emergente no pós-guerra - instiga a pensar como modos e comportamentos constituídos a partir de determinadas culturas se tornam válidos em contextos diversos com a legitimidade de serem os mais adequados.

A obra de Wilson, publicada originalmente em 1937, sob o título The new etiquete, foi traduzida e adaptada do inglês por Gilda Marinho ${ }^{5}$, pela primeira vez no Brasil, em 1945. O intuito de evidenciar vínculos culturais com os EUA foi explicitado pela tradutora na

\footnotetext{
${ }^{4}$ Nascida em 1896, no Kentucky (EUA), a autora passou pelas carreiras de atriz, editora e produtora de cinema e escritora. Fundou sua própria companhia de teatro aos 16 anos e saiu em turnê. Não obstante a breve passagem, foi proeminente em Hollywood, protagonizando alguns filmes e mais tarde consagrando-se como uma das pioneiras nas funções de editora e diretora de filmes, espaço ocupado em maioria por homens na época — e até hoje também. Uma de suas primeiras publicações foi fruto de projeto de programa de rádio, chamado Charm, que se expandiu para um livro, inicialmente publicado em 1928 e depois revisado e reproduzido muitas vezes como The woman you want to be: book of charm. Na sequência, continuou a produção, entre os quais foram publicados: The new etiquette (1937), versão original do livro utilizado neste estudo, e muitos outros até a década de 1980, quando encerrou sua carreira. Faleceu em 1986. Disponível em: https://wfpp.cdrs.columbia.edu/pioneer/ccp-margery-wilson/. Acesso em: 25 mai. 2017.

${ }^{5}$ Nascida em Pelotas, no ano de 1900, era porto-alegrense de coração, fez história na cidade, sobretudo na área cultural. Foi jornalista, uma das primeiras mulheres a trabalhar na imprensa gaúcha, tradutora, professora de Artes da UFRGS e atuou como colunista social durante muitos anos. Faleceu em 1984. Disponível em: http://portoalegre-rs.blogspot.com.br/2010/10/gilda-marinho.html. Acesso em: 25 mai. 2017.
} 


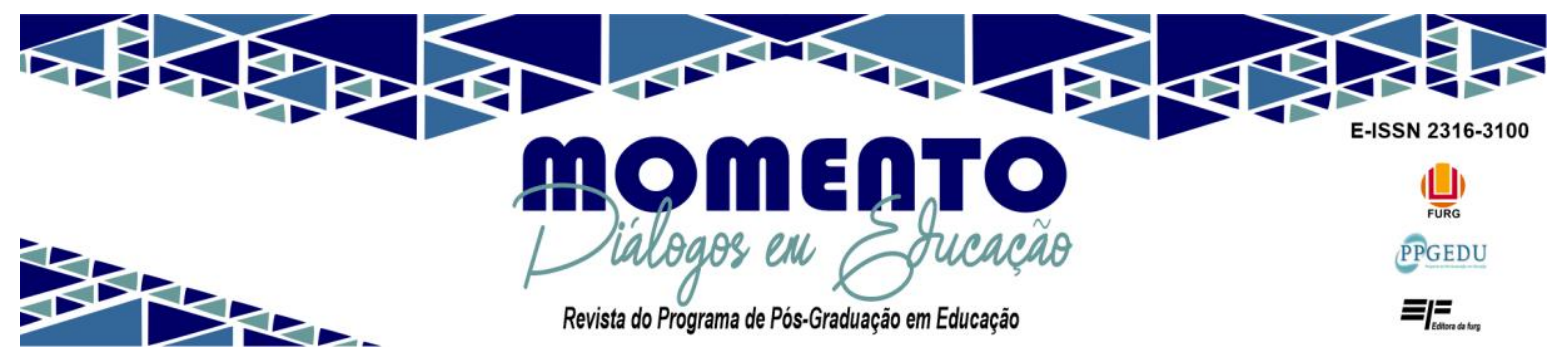

apresentação: "Somos vizinhos e amigos e, por conseguinte, com pequenas alterações inevitáveis, a mesma etiqueta que impera nos Estados Unidos rege também os nossos hábitos" (WILSON, 1947, p. 14). A narrativa de amizade entre os países, também mobilizada no "Relatório de término do projeto", suavizava um sentido civilizatório, ao mesmo passo que sinalizava interação entre as culturas. Todavia, não se pode invisibilizar a questão de que se trata de leituras de formação produzidas a partir de determinados modos, com o intuito de serem internalizados. Se no caso dos livros de boas maneiras eram leituras alternativas, no caso da coleção "Biblioteca de Orientação da Professôra Primária" eram leituras produzidas para serem institucionais ou mesmo políticas de Estado.

A idealização de modos e comportamentos construída pelas prescrições contidas nos manuais de boas maneiras ressoava sobre a instituição de novas culturas escolares, especialmente voltadas à formação do ser humano desde sua idade mais tenra. Na seção nomeada "Os objetivos do moderno Jardim de Infância", Abi-Sáber (1965, p. 24) sugere esta preocupação:

O Jardim de Infância tem por fim rodear a criança de um ambiente sadio, no qual ela possa viver e conviver bem com os colegas e com todos os membros do seu grupo, tornando-se, ao mesmo tempo, um bom elemento da sua sociedade.

A proposta do moderno Jardim de Infância - como é referenciado na obra - se apresenta como parte do processo civilizador do indivíduo, que se conecta ao processo social como um todo, uma vez que a escola seria o espaço de preparação para o acesso aos espaços de diferenciação social. Nessa esteira, a inserção social do indivíduo se dá a partir da participação, cada vez maior, nas cadeias entrelaçadas de interdependência, que são uma manifestação de "[...] todas as funções sociais que os indivíduos têm que desempenhar, e da pressão competitiva que satura essa rede densamente povoada e que afeta, direta ou indiretamente, cada ato isolado da pessoa" (ELIAS, 1993, p. 207). Dessa forma, um Jardim de Infância pode ser esse ambiente coletivo que afeta os indivíduos, configurando suas estratégias de ocupar funções e espaços sociais. A preparação para ser "um bom elemento da sua sociedade" é caracterizada como um processo ascendente e competitivo no qual a formação nessa idade, oferecida pelos Jardins de Infância, aumentaria as possibilidades de êxito social. Segundo o documento, 


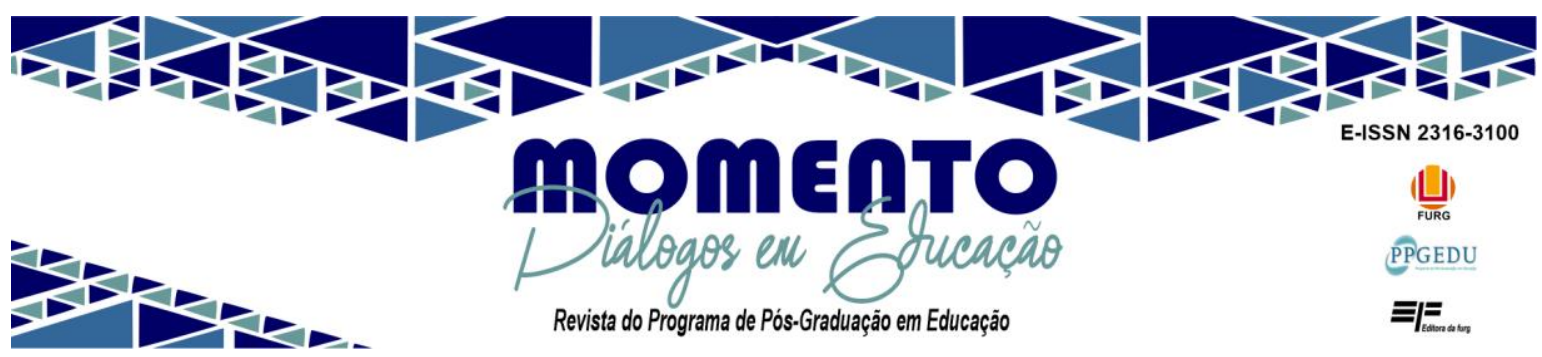

A preparação adequada das crianças através de exercícios específicos, atividades físicas e intelectuais, aquisições de experiências sociais e ajuste emocional, é uma garantia de sucesso na sua futura aprendizagem. Não é sem razão que um célebre pedagogo comparou a aventura escolar a uma corrida de competição; prevendo sempre a vitória para o corredor que vencer os cem primeiros metros. De fato, a arrancada inicial, decide a sorte de toda e qualquer batalha. Muito raramente essa regra encontra exceções (ABI-SÁBER, 1965, p. 22).

A argumentação qualifica a passagem por um Jardim de Infância como uma vantagem no contexto do processo formativo de uma criança. Nesse sentido, trata da preparação de indivíduos seletos, capazes de constituir uma sociedade de vitoriosos e ajustados. Essa narrativa recebe ênfase quando o texto destaca, no decorrer de sua redação, que '[...] 'os vencedores', a que aludimos antes, são aqueles que, realmente, foram preparados para alcançar a vitória. São aqueles que receberam 'tratamento' especial, isto é, foram treinados, através de atividades próprias para vida escolar e vida social" (ABISÁBER, 1965, p. 23). As ideias de normatização de condutas, treino para a vida e comportamentos aceitáveis estão aqui associadas ao ajustamento social, bem como ao alcance de vitórias. De alguma forma, a frequência no Jardim de Infância poderia instrumentalizar as crianças para um futuro bem-sucedido, dentro dos padrões entendidos como tal.

O período de publicação de "O que é o Jardim de Infância” coincide com publicações de obras que, assim como esta, reverberavam concepções, conceitos e construções provenientes da cultura estadunidense. A obra $O$ livro de etiqueta, da autora norte-americana Amy Vanderbilt ${ }^{6}$, foi traduzida por Abiah Lopes ${ }^{7}$ e publicada no Brasil em 1962, dez anos

\footnotetext{
${ }^{6}$ Nascida em 1908, em Nova Iorque, a autora iniciou sua carreira de jornalista com 16 anos e trabalhou em muitas funções como agente de publicidade e executiva de negócios do ramo literário, entretanto suas atividades profissionais foram maiores na função de escritora. Com a sua formação na Suíça e posterior formação em jornalismo pela Universidade de Nova Iorque, inseriu-se nos diversos estratos sociais como instrutora de costumes e formadora de hábitos. Foi anfitriã de programas de televisão e rádio, escrevia artigos da mesma demanda para revistas, jornais, folhetos, sugerindo um processo de compartilhamento de boas maneiras entre os muitos grupos sociais americanos, inclusive publicando quatro artigos na coluna "Boas maneiras na vida diária", do jornal $O$ Globo, no ano de 1958. No início da década de 1950, publicou o Amy Vanderbilt's complete book of etiquette (1952), original do livro utilizado neste estudo. Faleceu em 1974. Disponível

em: https://timesmachine.nytimes.com/timesmachine/1974/12/28/79373054.html?action=click\&contentCollectio $\mathrm{n}=$ Archives\&module=LedeAsset\&region=ArchiveBody\&pgtype=article. Acesso em: 25 mai. 2017.

${ }^{7}$ Escrevia sob o pseudônimo Sylvia Patrícia, era jornalista e colunista social carioca. Faleceu em 1975. Disponível em: https://acervo.oglobo.globo.com/consulta-ao-acervo/?navegacaoPorData=197019750514. Acesso em: 25 mai. 2017.
} 


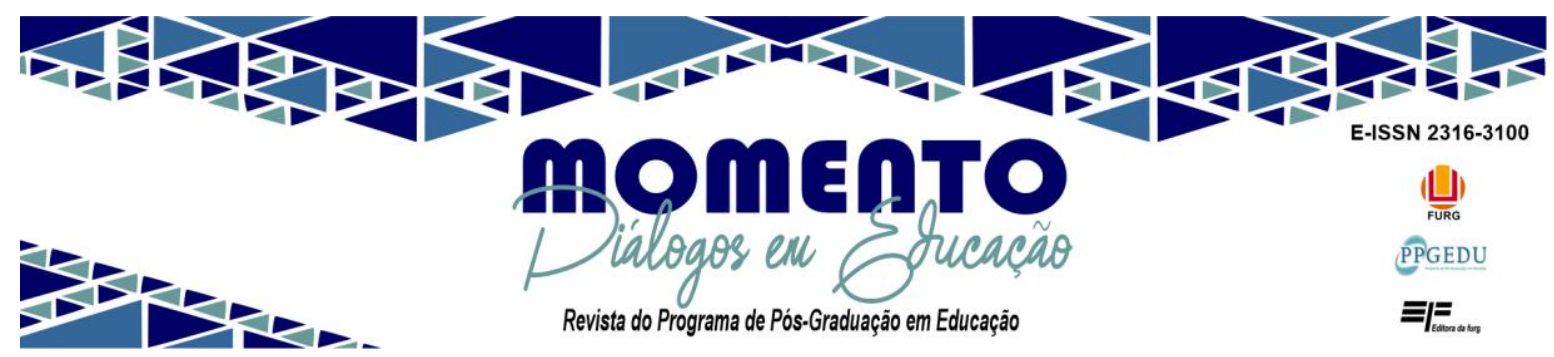

após a sua primeira publicação, sob o título Amy Vanderbilt's complete book of etiquette (1952). Na contracapa da obra, em um breve comentário sobre o livro, encontram-se indicativos de como foi pensado o processo de tradução dessa obra:

Escrito pela maior autoridade mundial em boas maneiras, esse livro trata de toda a tradicional etiqueta tal como é hoje praticada e foi adaptado aos costumes brasileiros no que eles têm de característico por autoridade no assunto (VANDERBILT, 1962, contracapa).

A tradução sinalizou a necessidade de uma adaptação das informações contidas no original com vistas a atender às demandas do público ao qual se destinava essa publicação. Não é possível inferir sobre alterações nos conteúdos, pelo fato de a edição original não fazer parte dos documentos deste estudo, mas sim pensar em adequações que consideraram os diferentes contextos espaciais, culturais e sociais sem se distanciar dos ideais universalizantes que inspiraram esse tipo de escrita sobre as boas maneiras.

O livro de Amy Vanderbilt fez menção específica à educação de crianças no que tange às boas maneiras. Foram escritos pela autora cinco subcapítulos para tratar da formação nessa fase da vida, a saber: "Formação de caráter infantil”, "Educação religiosa das crianças", "Adultos e crianças", "Adotando uma criança" e "Teenager". Os conteúdos contemplam a formação social de crianças e jovens nas mais diversas situações cotidianas. No subcapítulo "As crianças e a formação do caráter", o item nomeado "Para o Jardim da Infância e as crianças maiores" abordou a questão da vestimenta dos pequenos alunos como uma forma de construir pertencimento e identidade de grupo no ambiente escolar. Destacase aqui a presença de um item direcionado a essa fase de escolarização como um dos elementos importantes para a formação do caráter, segundo as concepções da autora. Essa preocupação dialoga com a própria ação do PABAEE-INEP na execução do Projeto da Educação Elementar.

A ideia da existência de modos universais, a desconsideração dos contextos culturais diversos, o uso da nomenclatura Jardim de Infância para o período inicial da escolarização, o entendimento acerca de ser um espaço de formação social e a concepção de que a passagem por esse espaço de formação qualifica a trajetória educacional são alguns dos aspectos que se configuram em ponto de intersecção entre os livros de boas maneiras importados e o projeto educacional empreendido no Programa em questão. Essa compreensão sugere a 


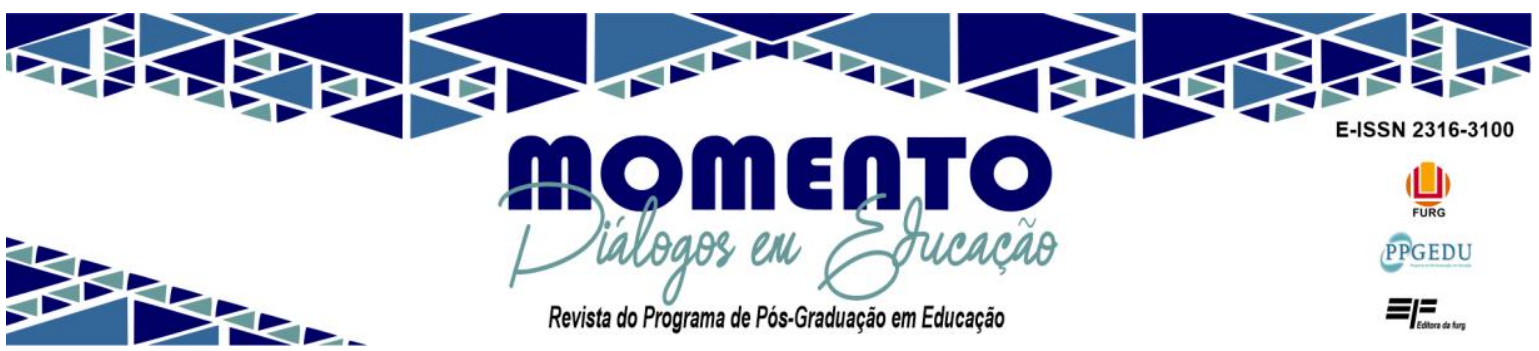

circulação de aspectos culturais estadunidenses em diversos meios e por diversos suportes, diminuindo, assim, as possíveis intercorrências que poderiam ocorrer ao instituir práticas em ambientes escolares diferentes daqueles onde já haviam apresentado êxito. Se a sociedade estivesse ambientada com os modos "americanizados", a escola estaria respaldada na instituição de novos projetos educacionais.

A importação de tais padrões disseminados pela leitura de livros de etiqueta e boas maneiras se relacionava à construção de um modo cultural sistemático abrangente que sugeria o compartilhamento de determinados modos como subsídio para viver em sociedade por meio da produção de identificações. Essas leituras estabeleciam redes de compartilhamento inserindo grupos da sociedade brasileira em um modo cultural global que se propagava nos meados do século XX. Estar conectado com essas narrativas importadas era significado de saber como as coisas aconteciam no mundo. Aspectos como o uso da língua sinalizavam a tecitura dessas conexões culturais, como, por exemplo, na redação do prefácio de "O que é um Jardim de Infância”, no trecho: “[...] alguns dos meios destinados a alcançar os 'goals' ou 'objetivos' da educação no Jardim de Infância” (ABI-SÁBER, 1965, p. 11), ou, na citação feita pela autora, usando as palavras do educador Abgar Renault: "A falta do que poderia denominar-se pré-escolaridade é tremendo 'handicap'[...]" (RENAULT, 1949 apud ABI-SÁBER, 1965, p. 17). A incorporação, seja escrita ou oral, de expressões em língua inglesa sinalizavam compartilhamento de concepções, sintonia com ideias e isso aproximava, ainda que de forma artificial, as culturas dos dois países, corroborando a afirmação de Gilda Marinho de que os mesmos princípios "regem" as duas sociedades.

A apropriação inventiva de vivências alheias ao meio brasileiro sugeria o tom e o ritmo de adequações a serem implantadas, para adultos, por meio da leitura, ou, para crianças, por meio de um sistema educacional. Em uma dinâmica vinculada à ideia de uma sociedade moderna, o espaço escolar funcionava como vetor de tal modernidade. Com a aplicação de modelos produzidos a partir de outras demandas, dispensava-se um referencial próprio, pensado a partir de demandas específicas da educação brasileira do período. Promovendo a inserção de concepções educacionais norte-americanas, foram inscritos hábitos que contribuíram na construção de memórias da cultura escolar de um tempo e, 


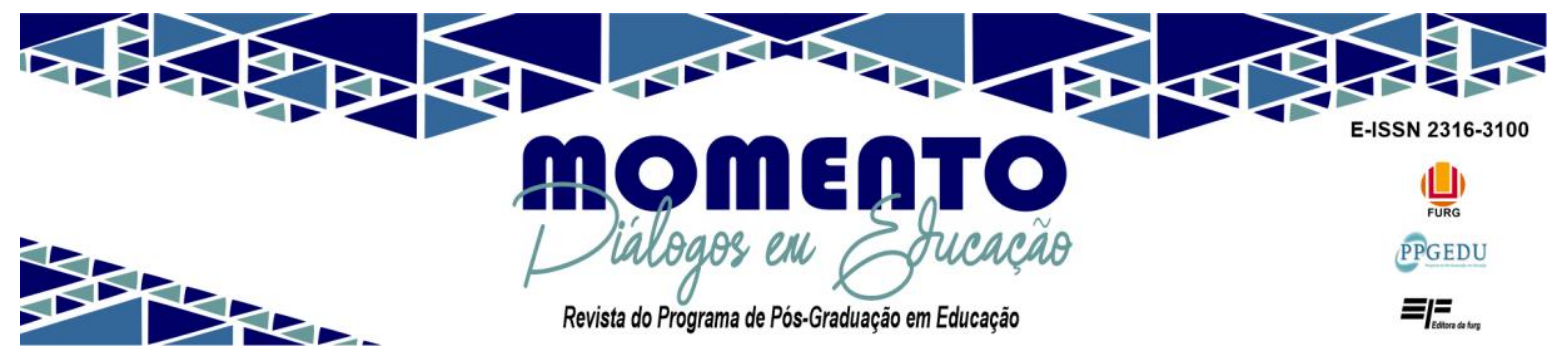

utilizando a via institucional, permaneceram como parte de um projeto nacional de escolarização, contemplando a formação de indivíduos preparados para a sociedade idealizada naquele período.

Construindo diálogo por diversas vias, as narrativas de Amy Vanderbilt também circularam no jornal $O$ Globo, alocadas no caderno "O Globo feminino", na coluna "Boas maneiras na vida diária”. Ao longo do ano de 1958, por exemplo, Amy Vanderbilt teve quatro textos publicados na coluna ${ }^{8}$. As publicações eram direcionadas ao público feminino, com o intuito formativo anunciado, tratando de questões do convívio social em âmbito público ou privado. Os textos da coluna apareciam com a ênfase de serem exclusivos para o jornal, indicando uma conexão internacional. A presença de Amy Vanderbilt n'O Globo enfatizou a circulação de suas prescrições no Brasil, bem como é mais um indício do espaço ocupado por construções sociais advindas dos EUA. A cultura estadunidense ressoava sua circulação por vias comerciais ou institucionais. Nesse sentido, o PABAEE-INEP também teve a preocupação de marcar presença no território brasileiro, pois essa era uma forma de instituir os Jardins de Infância e, por conseguinte, seus modos sociais.

\section{Circulação e difusão do PABAEE-INEP}

O uso dos manuais do PABAEE-INEP evidencia o desejo de construção de um novo modelo social, repleto de mecanismos nos quais os sujeitos pudessem se autogovernar, tendo a infância e professores(as) como alvo preferencial desse discurso institucional. Para atingir o alcance esperado, o Programa tinha em sua centralidade promover a modernização educacional, investindo em duas frentes de atuação: o treinamento dos profissionais e a difusão dos materiais didáticos, ambos podendo ser analisados de forma conjunta, ao compreender que os(as) professores(as) que estavam em cursos nesse convênio recebiam "vasto material didático. [...] como um oásis de fartura de material didático e privilégios (ônibus que levava e trazia os professores de casa até o trabalho, gratificações por tempo integral de trabalho etc.)" (PAIVA, PAIXÃO, 2002, p. 45).

\footnotetext{
${ }^{8}$ Os títulos das publicações foram os seguintes: "Não se indica preferência por presentes" (22 fev. 1958), "Duração de visitas informais" (5 abr. 1958), "Comportamento à mesa" (10 maio 1958) e "Reuniões de família" (23 ago. 1958).
} 


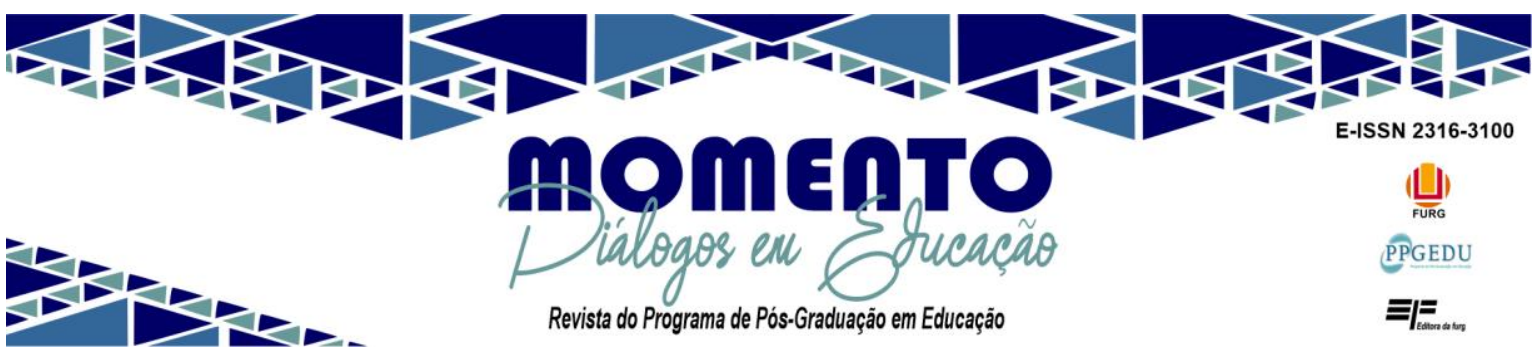

A disponibilidade ampliada de materiais e privilégios sinaliza o empenho estatal em efetivar um projeto educacional circunscrito por um repertório de representações e práticas com potencial de transformar modos sociais e contribuir para um país modernizado e conectado com tendências internacionais. Em diálogo com Elias (1993), quando aponta que a dinâmica dos processos sociais se dá pela transformação no entrelaçamento e na interdependência humanos, bem como pela monopolização da força por parte das instituições, percebe-se um intuito transformador viabilizado por projetos educacionais empenhados pelo Estado. Com efeito, a abordagem pela escolarização se apresenta como uma oportunidade de constituir bases significativas para gerações futuras. Legitimadas no presente por meio de uma narrativa de modernização, as transformações culturais, que se movimentam em longa duração, são aceleradas por processos formativos da fase inicial da escolarização. $\mathrm{O}$ incentivo estrutural e o financeiro do governo facilitariam sobremaneira a abrangência territorial do projeto.

No relatório do Programa, no item "Distribuição das publicações do PABAEE", é possível observar alguns indícios sobre a circulação desses impressos em território nacional:

\begin{abstract}
A lista de distribuição das publicações do PABAEE foi revista muitas vêzes. Uma grande parte da produção nos anos iniciais foi distribuída gratuitamente a fim de promover e divulgar a contribuição do Programa de educação primária no Brasil. Já em 1964, a distribuição limitou-se a cêrca de um quinto da produção total. O restante foi vendido a prêço de custo. A lista de distribuição gratuita, aprovada em Janeiro de 1964, incluía as Secretarias de Educação de todos os Estados, os seis centros regionais do INEP, professôres e diretores do Instituto de Educação de Belo Horizonte, chefes de secção das Secretarias de Educação, Aliança para o Progresso (Recife), USAID/Rio, e muitas bibliotecas educacionais. O número total de exemplares de distribuição gratuita, em Janeiro de 1964, era de 1.011 (PROGRAMA DE ASSISTÊNCIA..., 1964, p. 28).
\end{abstract}

Observando o interesse em fazer circular as metodologias consideradas modernas desse convênio, é possível indagar sobre as exigências atribuídas para a constituição de um modelo educacional e a própria construção modular do ser professora, que podem ser observadas nas prescrições contidas nos manuais, indicando como agir, a escolha de conteúdos e como trabalhá-los, instruções que buscavam delinear um modo de ser professor(a) e, consequentemente, um novo modo de ser aluno(a). De modo geral, buscavam 


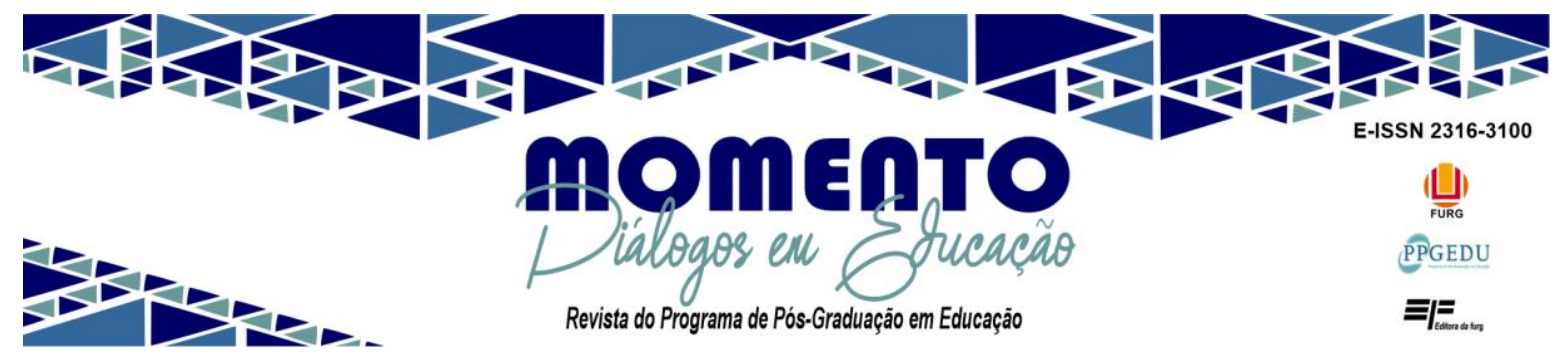

docilizar os corpos, considerados incivilizados, ao olhar dos técnicos estadunidenses. Em consonância com Oliveira (2007, p. 272), quando afirma que “[...] o corpo físico passava a ser talvez a principal possibilidade de reordenação do corpo político da sociedade", se fazia importante estabelecer limites para os corpos muito jovens que habitavam os Jardins de Infância, pois, assim, esses grupos seriam preparados para ocupar determinados espaços e continuar determinadas práticas, ainda que sob a égide da modernidade.

Essa percepção sobre a educação brasileira se justificava por uma visão mais abrangente acerca da cultura dos países. Alguns indícios sobre esta emergiram na mobilização de autores(as) norte-americanos(as) para ilustrarem periódicos, como no caso de Amy Vanderbilt e sua coluna n'O Globo, ou mesmo na redação de prefácios ou orelhas para obras daquele país que sinalizavam não somente a admiração, mas também o senso de hierarquia entre os países. As construções culturais eram qualificadas a partir do momento em que uma proeminente editora brasileira oferecia aos seus leitores a tradução de uma publicação, afirmando que "[...] nos Estados Unidos este tratado de boas maneiras constitui um código quase oficial" (WILSON, 1947, orelha). A obra de Margery Wilson foi apresentada como um conjunto de prescrições legitimadas por leitores norte-americanos e sugeriu a sua ampla circulação. No Brasil, há indícios que duas edições tenham sido produzidas sem qualquer referência à tiragem, entretanto, considerando o grupo leitor do país no ano de 1947, é possível pensar em uma demanda considerável. A importância dessa observação recai sobre a valorização da cultura norte-americana e a relevância de sua apropriação entre alguns grupos sociais. Essa conexão configurava um elemento daquilo que era considerado moderno.

Ao entrever a difusão das publicações do PABAEE, pode-se considerar que os manuais escolares contribuíram na tentativa de forjar novas mentalidades, na medida em que se vivia o entusiasmo da modernização ancorado no Plano de Metas de JK - o que não significa dizer que não houve críticas, resistências e táticas criadas para se contrapor ao modelo impositivo. Entretanto, todo o investimento no modo de ser professora primária sugere que esses impressos não eram um simples depósito de conteúdos escolares, mas sim estavam impregnados de um conjunto de elementos que perpassam o campo do gênero, da moral, da disciplina que, somados, constituíam como mecanismo disciplinador e pronto para formar um novo jeito de ser professora. Nessa esteira, tais conteúdos se configuravam em 


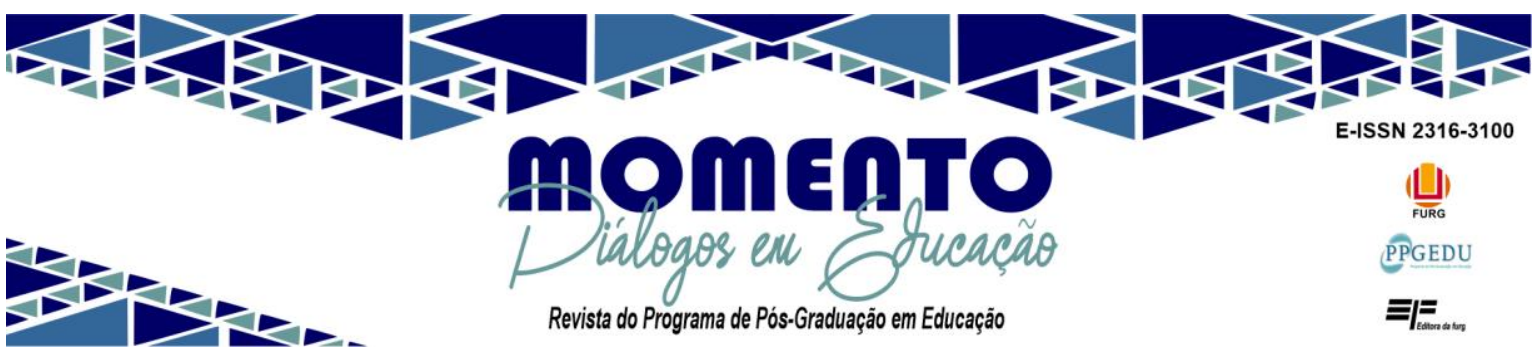

saberes escolares - para além dos currículos —, que eram mobilizados cotidianamente por professoras, compreendidas no âmbito do PABAEE-INEP como agentes da transformação desejada.

A difusão do convênio pode ser também percebida pelo alcance que o Programa almejou, o que se expressa na participação de professoras(es) de diferentes estados brasileiros e de alguns países vizinhos: o relatório produzido pelos técnicos do Programa apresenta que 10.346 professores e técnicos educacionais haviam participado dos cursos de aperfeiçoamento (Figura 2).

Figura 2: Abrangência do PABAEE-INEP (1956-1964).

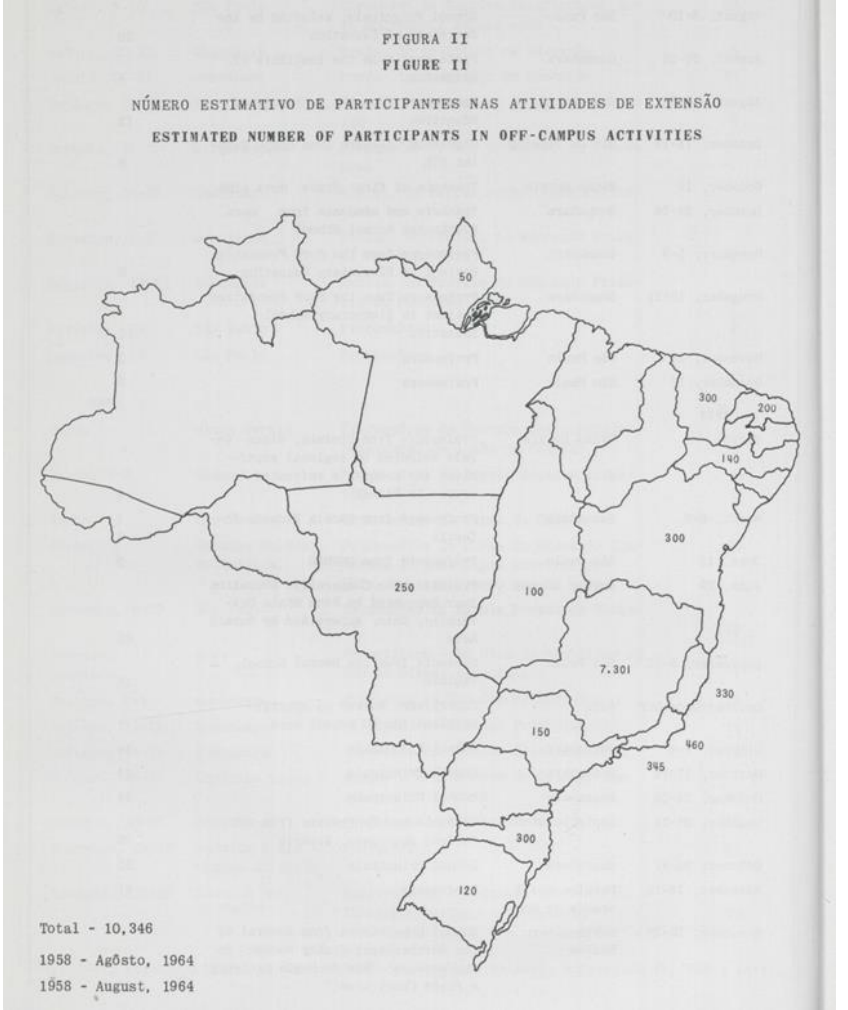

Fonte: Relatório do Programa de Assistência Brasileiro-Americana ao Ensino Elementar - PABAEE (PROGRAMA DE ASSISTÊNCIA..., 1964, p. 38).

Observando os dados sobre a abrangência do convênio, pode-se pensar na circulação de conhecimentos educacionais para além da circulação de seus manuais, mas, sobretudo, atentando para a difusão dos conhecimentos adquiridos que posteriormente seriam difundidos pelos(as) professores(as) cursistas. 


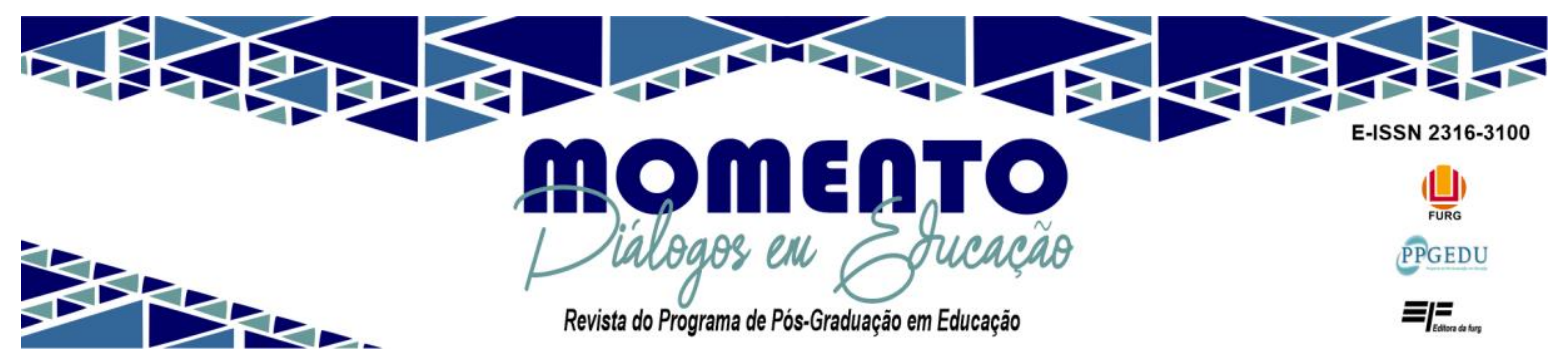

Seleção de Bolsistas do PABAEE - A matrícula nos cursos do PABAEE pressupunha a aprovação da Secretária de Educação dos Estados, do Instituto Nacional de Estudos Pedagógicos (INEP) e do PABAEE. A aprovação baseou-se no exame das potencialidades do candidato, reveladas por sua experiência profissional e estudos; e ainda, no compromisso da Secretária de Educação no sentido de nomear o candidato para uma posição de liderança em educação, depois de sua permanência no PABAEE (PROGRAMA DE ASSISTÊNCIA..., 1964, p. 15).

Segundo o Relatório, a escolha de professores(as) selecionados(as) a viajarem à capital mineira ocorria sob o aval dos secretários estaduais de educação, no contexto em que muitos(as) professores(as) que realizaram os cursos assumiram cargos em suas secretarias municipais e estaduais atuando como difusores(as) dos conhecimentos adquiridos. Ou seja, a difusão ocorria por meio da atuação em diversos estados e municípios brasileiros.

Na Figura 2, a indicação no mapa dos estados originários dos professores sugere a preocupação em formar profissionais provenientes de todas as regiões do país. A disponibilização de materiais era uma maneira de multiplicar os ensinamentos empreendidos nos cursos. Alguns aspectos das culturas escolares, segundo Faria Filho (2007, p. 195), “[...] permitem que a escola funcione como uma agência criadora e conservadora da cultura por meio de uma intensa prática de apropriação em relação às estruturas mais gerais em que ela está situada". A formação de professores(as) que atuavam em diversos estados brasileiros permitiria a difusão da proposta nos mais diversos ambientes com a potência de um saber escolar. A ideia de transformar os participantes das formações em gestores educacionais estaduais e municipais conferia o lastro necessário para esse processo de apropriação de outras culturas, se espraiando pelas "estruturas mais gerais" referidas por Faria Filho. Dessa forma, em tese, o processo inicial de escolarização ia ao encontro dos projetos modernizadores inspirados na cultura estadunidense, considerada, naquele momento, digna de reprodução e continuidade.

\section{Considerações}

O período posterior à Segunda Guerra Mundial foi, para os norte-americanos, um momento ímpar para exportar produtos e modelos culturais. $\mathrm{O}$ acordo que deu origem ao PABAEE-INEP no Brasil se inscreve nesse contexto — portanto, esteve imbuído de intuitos 


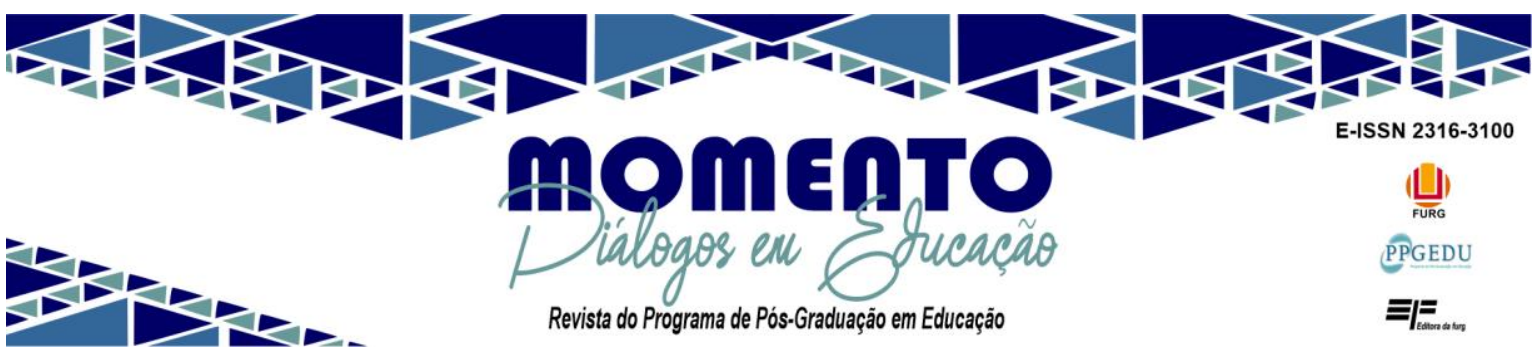

modernizadores e universalizantes. A cultura estadunidense chegou ao país de diversas formas, e a literatura de boas maneiras mostrava a sintonia com as práticas sociais que mais evidenciavam um processo civilizacional aceito. Esse tipo de material contribuiu na construção das maneiras nos grupos sociais que demandavam ilustração e convívio com classes economicamente abastadas. Na mesma esteira, suas crianças precisavam adentrar esse universo simbólico muito precocemente para que crescessem imbuídos dos modos que lhes auxiliariam a ser vencedores em sua trajetória social. A coleção "Biblioteca de Orientação da Professôra Primária" apresentou os pressupostos formativos para as professoras que receberam essa "missão". Mais do que um processo formativo, o que esteve em pauta foi um processo de transformação social pelas instituições escolares.

A escolha pela análise de documentos que circularam fora e dentro do contexto escolar foi ao encontro de jogar luz sobre a apropriação de elementos culturais norteamericanos na sociedade brasileira daquele período. Ainda que a falta de acesso à circulação dos livros de boas maneiras limitasse a reverberação dessas narrativas, os documentos indicaram a sua presença em outros suportes, bem como a preocupação em formar professoras de todas as regiões do país para que multiplicassem aqueles pressupostos educacionais, ampliando, assim, o eco de tais narrativas.

Todos os preceitos apresentados para a construção de uma sociedade moderna por via educacional, em especial nos manuais desse convênio, partiam do pressuposto de que as boas maneiras eram passíveis de serem ensinadas/aprendidas no ambiente escolar, de acordo com o olhar de seus idealizadores. Desse modo, a escola abraçaria todos aqueles que "desejassem" se incluir nesta sociedade rumo à modernização. Para essa eficiência, bastaria utilizar com eficiência os recursos, as ideias e os métodos de ensino - o que coloca como responsabilidade de professores(as) e escolas nesse projeto empreendido, sem muitas vezes considerar o contraponto do Estado na ampliação e construção de espaços educacionais pensados a partir de uma realidade própria e específica da sociedade a que se destina.

\section{Referências}

BRASIL. Lei $\mathbf{n}^{\circ}$ 1.920, de 25 de julho de 1953. Cria o Ministério da Saúde e dá outras providências. Rio de Janeiro: Presidência da República, 1953. Disponível em: 


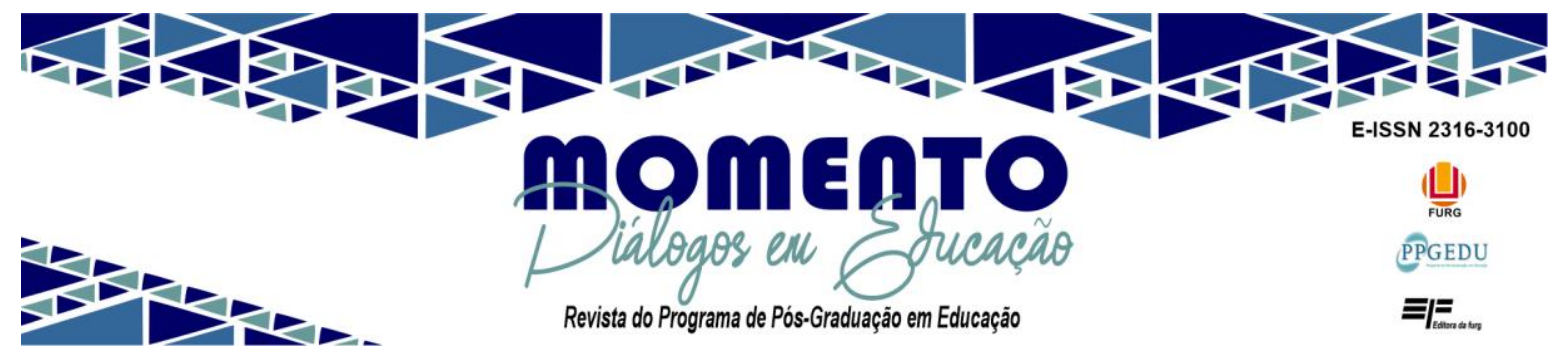

http://www.planalto.gov.br/ccivil_03/leis/1950-1969/11920.htm. Acesso em: 15 set. 2021.

CHOPPIN, Alain. O historiador e o livro escolar. História da Educação, Pelotas, v. 6, n. 11, p. 5-24, jan./jun. 2002. Disponível em: https://seer.ufrgs.br/asphe/article/view/30596/pdf. Acesso em: 20 abr. 2020.

CHARTIER, Roger. A história cultural: entre práticas e representações. Lisboa: Difel; Rio de Janeiro: Bertrand, 1990.

CUNHA, Maria Teresa Santos. História, educação e civilidades: a correspondência como um saber escolar na Escola Normal entre as décadas de 1930 e 1960. Educação, Santa Maria, v. $30, \quad$ n. 2 , p. 121-138, jul./dez. 2005. Disponível em: https://periodicos.ufsm.br/reveducacao/article/view/3742/2146. Acesso em: 15 jun. 2018.

ELIAS, Norbert. O processo civilizador. Volume 2: formação do Estado e civilização. Rio de Janeiro: Jorge Zahar, 1993.

FARIA FILHO, Luciano Mendes. Escolarização e cultura escolar no Brasil: reflexões em torno de alguns pressupostos e desafios. In: BENCOSTTA, Marcus Levy. Culturas escolares, saberes e práticas educativas: itinerários históricos. São Paulo: Cortez, 2007. p. 193-211.

O GLOBO. Acervo virtual. Rio de Janeiro, 22 fev. 1958, p. 9. Disponível em: https://acervo.oglobo.globo.com/consulta-ao-acervo/?navegacaoPorData=195019580222.

Acesso em: 10 mai. 2018.

OLIVEIRA, Marcus Aurélio Taborda de. Educando pelo corpo: saberes e práticas na instrução pública primária nos anos finais do século XIX. In: BENCOSTTA, Marcus Levy. Culturas escolares, saberes e práticas educativas: itinerários históricos. São Paulo: Cortez, 2007. p. 265-300.

PAIVA, Edil Vasconcellos; PAIXÃO, Lea Pinheiro. PABAEE (1956-1964): a americanização do ensino elementar no Brasil? Niterói: EdUFF, 2002.

WASCHINEWSKI, Susane Costa. Jessy Cherem (1929-2014): percursos da professora catarinense e seu arquivo em três tempos. 2020. Tese (Doutorado em Educação) - UDESC, Florianópolis, $2020 . \quad$ Disponível em: https://www.udesc.br/arquivos/faed/id_cpmenu/296/SUSANE_DA_COSTA_WASCHINE WSKI_Tese_16154914620243_296.pdf. Acesso em: 13 set. 2021.

WASCHINEWSKI, Susane Costa; RABELO, Giani. aprovar para modernizar: primeiro plano estadual de educação de Santa Catarina (1969/1980) e o sistema de avanço progressivo. Revista Tempos e Espaços em Educação, São Cristóvão, v. 12, n. 30, p. 139154, 2019. Disponível em: https://seer.ufs.br/index.php/revtee/article/view/9384. Acesso em: 05 abr. 2020. 


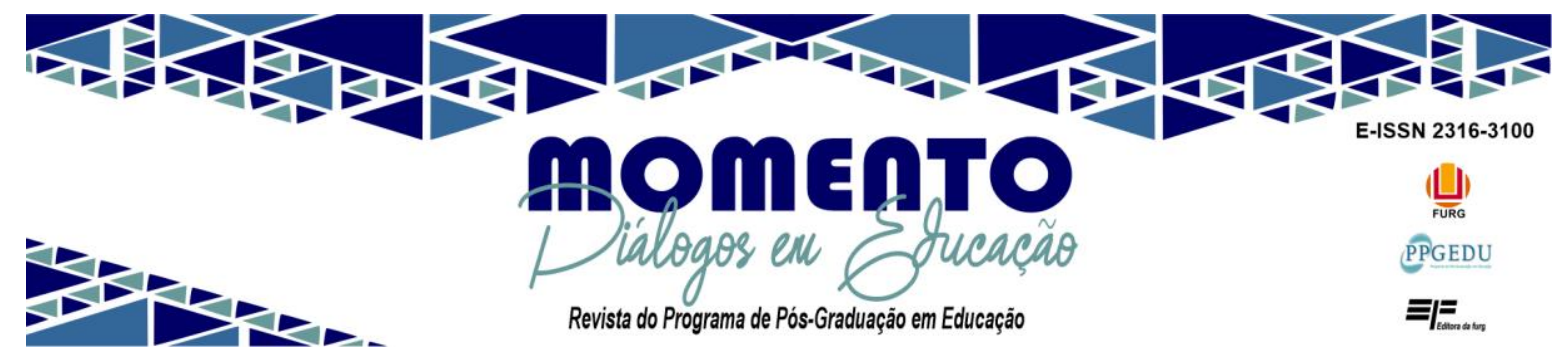

Fontes documentais

ABI-SÁBER, Nazira Féres. O que é Jardim da Infância. Rio de Janeiro: Editora Nacional de Direito, 1965.

PROGRAMA DE ASSISTÊNCIA BRASILEIRO-AMERICANA AO ENSINO ELEMENTAR. Relatório do Programa de Assistência Brasileiro-Americana ao Ensino Elementar (1956-1964). Belo Horizonte: Centro de Artes Gráficas do PABAEE, 1964.

VANDERBILT, Amy. O livro de etiquêta: um guia para uma vida elegante. Rio de Janeiro: Record, 1962.

WILSON, Margery. Cortesia: novo código social das boas maneiras. Rio de Janeiro: Livraria do Globo, 1947.

Submissão em: 17-08-2021

Aceito em: 18-09-2021 